\title{
ANALISIS KINERJA INSTALASI PENGOLAHAN AIR LIMBAH DOMESTIK STUDI KASUS PT. UNITED CAN Co. Ltd.
}

\author{
Rudi Nugroho \\ Pusat Teknologi Lingkungan, BPPT \\ JI. M.H. Thamrin No. 8 Gd. II Lt. 18 Jakarta 10340
}

\begin{abstract}
Nowadays, the domestic wastewater have become a big problem in Indonesia especially in Jakarta. The governor of DKI Jakarta has established new regulation of domestic wastewater standard which can be discharge to the environment. The regulation namely Pergub 122 tahun 2005. To comply the regullation, PT. United Can Co. Ltd. has already built a domestic wastewater treatment using anaerobic-aerobic biofilter. The wastewater treatment has $130 \mathrm{~m}^{3} /$ day of treatment capacities. During the start-up periods till 3 months running, the compossition of influent and efluent were analysed weekly. The results show that the concentration of parameter of COD, BOD, TSS, Amonia, $\mathrm{pH}$ and MBAS in the effluent have bellow the limit noted in the Pergub 122 th 2005.
\end{abstract}

Keywords: Domestic Wastewater, Biofilter, Anaerobic, Aerobic

\section{PENDAHULUAN}

Masalah pencemaran lingkungan oleh air limbah saat ini sudah sampai pada tahap yang mengkhawatirkan seperti halnya di DKI Jakarta. Beban polutan organik yang dibuang ke badan sungai atau lingkungan di DKI sudah sampai pada tahap dimana alam atau lingkungan sudah tidak mampu lagi melakukan pemurnian secara alami. Dampaknya antara lain pencemaran sungai maupun teluk Jakarta yang mengakibatkan kepada kematian ikan. Ironisnya, sumber pencemar dominan di DKI bukanlah dari kegiatan industri yang sering dituding sebagai penyebab utama, melainkan dari sumber domestik/rumah tangga (8).

Berdasarkan hasil penelitian yang dilakukan oleh Dinas Pekerjaan Umum (PU) DKI Jakarta bersama-sama dengan Tim JICA (1989), jumlah unit air buangan dari buangan domestik (kegiatan rumah tangga) per orang per hari adalah 118 liter dengan konsentrasi BOD ratarata $236 \mathrm{mg} / \mathrm{lt}$ dan pada tahun 2010 nanti diperkirakan akan meningkat menjadi 147 liter dengan konsetrasi BOD rata-rata $224 \mathrm{mg} / \mathrm{lt}$.

Berdasarkan survey di Jakarta tahun 1989, tiap orang rata-rata mengeluarkan beban limbah organik sebesar 40 gram BOD per orang per hari, yakni dari limbah toilet 13 gram per orang per hari dan dari limbah non toilet sebesar 27 gram BOD per orang per hari. Jika hanya air limbah toilet yang diolah dengan sistem tangki septik dengan efisiensi pengolahan $65 \%$, maka hanya $22,5 \%$ dari total beban polutan organik yang dapat dihilangkan, sisanya $77,5 \%$ masih terbuang keluar.

Pabrik kemasan kaleng PT. United Can Company Limited yang selanjutnya disebut PT.
UCC yang beralamat di Jalan Raya Daan Mogot Km 17 Semanan Jakarta Barat, tahun 2006 telah membangun sarana pengolahan air limbah domestik yang memenuhi persyaratan dan air hasil olahannya sebagian besar digunakan kembali (re-use). Sebelum dibangunnya IPAL, air Limbah domestik yang dihasilkan dari WC (Water Closet) diolah dengan tangki septik konvensional dan air limbah dari toilet, kamar mandi dan kantin karyawan masih dialirkan ke perairan sekitar tanpa melalui pengolahan sama sekali.

Dalam makalah ini diulas mengenai sistem pengolahan air limbah domestik yang ada di PT. UCC yang mencakup kriteria perencanaan, uraian proses IPAL dan evalusi kinerja IPAL selama periode 3 bulan awal operasi.

\section{IPAL DOMESTIK PT. UNITED CAN}

IPAL domestik PT. UCC dirancang untuk mengolah air limbah dari kantin, toilet, kamar mandi dan mushola yang ada di lokasi pabrik. Sumber limbah domestik ini letaknya terpencarpencar. Teknologi proses yang digunakan adalah dengan system biofilter anaerob-aerob dengan media isian plastik tipe sarang tawon hasil kajian tim Peneliti Pusat Teknologi Lingkungan BPPT (6). Bangunan IPAL terbuat dari beton bertulang seperti terlihat pada gambar 2 .

\subsection{Penentuan Kapasitas IPAL}

Penentuan kapasitas IPAL domestik umumnya dapat dihitung berdasarkan jumlah karyawan atau dapat juga dihitung berdasarkan kebutuhan air setiap harinya (6). Pemakaian air per hari di UCC untuk keperluan domestik adalah 
sekitar $80 \mathrm{~m}^{3}$. Dari jumlah ini $80 \%$ nya terbuang sebagai limbah domestik, Jadi berdasarkan pemakaian air, air limbah domestik yang dihasilkan per hari di perkirakan sebanyak $64 \mathrm{~m}^{3}$ per hari.

Jumlah karyawan di PT. UCC sekitar 1400 orang. Dari referensi maupun Pergub DKI 122 tahun 2005 tentang limbah domestik, pemakaian air oleh karyawan di suatu Industri adalah 70 liter per orang per hari. Apabila $80 \%$ nya dibuang menjadi limbah domestik, maka air limbah domestik yang dihasilkan oleh PT. UCC dihitung berdasarkan jumlah karyawan adalah sekitar $78 \mathrm{~m}^{3}$ per hari.

Dalam menentukan kapasitas IPAL, perlu dipertimbangkan faktor keamanan dan kemungkinan pengembangan dari Industri yang bersangkutan. Dengan mempertimbangkan faktor tersebut diatas, maka diputuskan kapasitas IPAL sebesar $130 \mathrm{~m}^{3}$ per hari. Angka ini sudah sangat aman untuk PT. United Can.

\subsection{Kriteria Kualitas air IPAL Domestik}

Tabel 2 menunjukkan kualitas air yang dipersyaratkan untuk dapat diolah di IPAL domestik PT. UCC. Melihat konsentrasi yang ditetapkan, angka COD, BOD, SS maupun debit sudah berada di angka yang aman sebagai dasar perencanaan IPAL.

Tabel 2. Kualitas Air Limbah Yang Diijinkan Masuk IPAL

\begin{tabular}{|c|c|c|}
\hline No & PARAMETER & Konsentrasi \\
\hline 1 & COD mg/l & 600 \\
\hline 2 & BOD mg/l & 300 \\
\hline 3 & SS mg/l & 200 \\
\hline 4 & DEBIT m3/hari & 130 \\
\hline
\end{tabular}

Kualitas air hasil olahan IPAL yang di targetkan adalah memenuhi standar baku mutu yang tertuang dalam Peraturan Gubernur No. 122 Tahun 2005. Parameter nya seperti yang ada pada tabel 3 di bawah ini:

Tabel 3. Baku Mutu Limbah Cair Domestik Komunal ${ }^{(5)}$

\begin{tabular}{|l|l|l|l|}
\hline No. & PARAMETER & SATUAN & BESARAN \\
\hline 1. & $\mathrm{pH}$ & - & $6-9$ \\
\hline 2. & $\begin{array}{l}\text { Kalium } \\
\text { permanganate } \\
\left(\mathrm{KMnO}_{4}\right)\end{array}$ & $\mathrm{mg} / \mathrm{l}$ & 85 \\
\hline
\end{tabular}

\begin{tabular}{|l|l|l|l|}
\hline 3. & $\begin{array}{l}\text { Total suspended } \\
\text { solid (TSS) }\end{array}$ & $\mathrm{mg} / \mathrm{l}$ & 50 \\
\hline 4. & Amonia $\left(\mathrm{NH}_{3}-\mathrm{N}\right)$ & $\mathrm{mg} / \mathrm{l}$ & 10 \\
\hline 5. & Minyak \& lemak & $\mathrm{mg} / \mathrm{l}$ & 10 \\
\hline 6. & $\begin{array}{l}\text { Detergen } \\
\text { (MBAS) }\end{array}$ & $\mathrm{mg} / \mathrm{l}$ & 2 \\
\hline 7. & $\begin{array}{l}\text { Biochemical } \\
\text { oxygen demand } \\
\text { (BOD5) }\end{array}$ & $\mathrm{mg} / \mathrm{l}$ & 50 \\
\hline 8. & $\begin{array}{l}\text { Chemical oxygen } \\
\text { demand (COD) }\end{array}$ & $\mathrm{mg} / \mathrm{l}$ & 80 \\
\hline
\end{tabular}

Sedangkan kualitas air yang ditargetkan dari proses re-use adalah seperti pada tabel 4

Tabel 4. Kualitas Air Hasil Proses Re-use

\begin{tabular}{|c|c|c|c|}
\hline No. & PARAMETER & SATUAN & BESARAN \\
\hline 1. & $\mathrm{pH}$ & - & $6-9$ \\
\hline 2. & $\begin{array}{l}\text { Kalium } \\
\text { permanganate } \\
\text { (KMnO4) }\end{array}$ & $\mathrm{mg} / \mathrm{l}$ & $<20$ \\
\hline 3. & $\begin{array}{l}\text { Total suspended } \\
\text { solid (TSS) }\end{array}$ & $\mathrm{mg} / \mathrm{l}$ & $<5$ \\
\hline 4. & Amonia $\left(\mathrm{NH}_{3}-\mathrm{N}\right)$ & $\mathrm{mg} / \mathrm{l}$ & $<0,1$ \\
\hline 5. & Minyak \& lemak & $\mathrm{mg} / \mathrm{l}$ & $<1$ \\
\hline 6. & $\begin{array}{l}\text { Detergen } \\
\text { (MBAS) }\end{array}$ & $\mathrm{mg} / \mathrm{l}$ & $<0,2$ \\
\hline 7. & $\begin{array}{l}\text { Biochemical } \\
\text { oxygen demand } \\
\left(\mathrm{BOD}_{5}\right)\end{array}$ & $\mathrm{mg} / \mathrm{l}$ & $<10$ \\
\hline 8. & $\begin{array}{l}\text { Chemical oxygen } \\
\text { demand (COD) }\end{array}$ & $\mathrm{mg} / \mathrm{l}$ & $<20$ \\
\hline
\end{tabular}

\subsection{Unit Bangunan dan Peralatan IPAL}

IPAL PT. UCC secara garis besar terdiri dari 3 sistem yaitu sistem pengumpulan air limbah, sistem IPAL dan sistem re-use air limbah. Untuk IPAI sistem re-use dibangun pada satu lokasi ahan seluas $240 \mathrm{~m}^{2}$. IPAL ini tediri dari unit-unit pemroses yaitu :

- Unit Bak Equalisasi,

- Unit Bak Pengendap Awal,

- Unit Bak Biofilter Anaerob,

- Unit Biofilter Aerob,

- Unit Bak Pengendap Akhir,

- Unit Bak Biofilter Pengolah Lanjut,

- Unit Penampung Proses Olahan IPAL,

- Unit Karbon Filter,

- Unit Bak Penampung Feed Ultrafiltrasi,

- Unit Ultrafiltrasi (UF),

- Unit Penampung Akhir. 


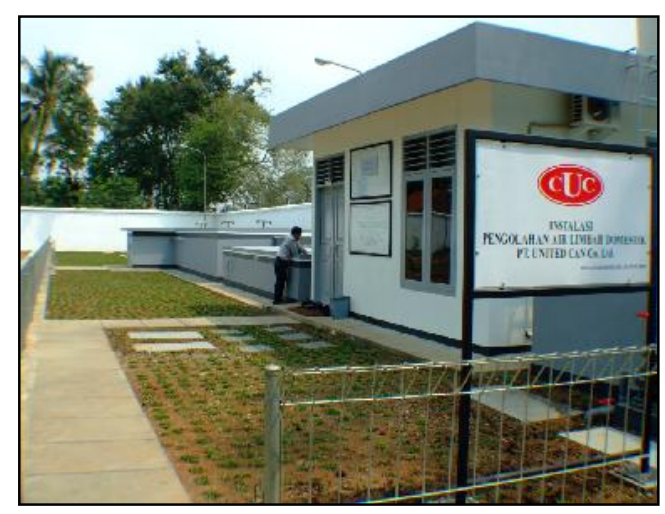

Gambar 2. Foto IPAL Domestik PT. UCC dengan Biofilter Anaerob-aerob

\subsection{Sistem Pengumpulan Air Limbah Domestik}

Penanganan yang dilakukan untuk mengolah air limbah domestik dengan IPAL, adalah seluruh air limbah yang dihasilkan dari kegiatan domestik pabrik dialirkan menuju ke Bak Pengumpul (BP). Dari BP dialirkan menuju ke IPAL dengan sistem perpompaan. Khusus untuk air limbah dari WC, dialirkan ke dalam septik tank, kemudian air limpasan dari septik tank ditampung ke dalam bak pengumpul (BP) untuk selanjutnya dialirkan menuju ke IPAL. Jumlah keseluruhan BP ada 12 unit. Skema aliran limbah ke IPAL dapat dilihat pada gambar 3 pada lampiran.

Bak pengumpul dibuat dalam 2 ruangan seperti terlihat pada gambar 4-5. Antara ruang pertama dan ruang kedua dipasang perpipaan dilengkapi dengan Tee. Sistem Tee ini dimaksudkan untuk menahan kotoran yang mengapung seperti minyak, lemak, kotoran padat, plastik, saset sampo, karet dan lain-lain sehingga tidak masuk ke ruang kedua. Pada ruang kedua dipasang pompa submersible dan pompa centrifugal (BP 4, BP7 dan BP 12), Pompa dilengkapi dengan sistem otomatis yang akan bekerja pada saat ada air sampai ketinggian tertentu. Tipe pompa pada tiap tiap bak pengumpul beserta kebutuhan listriknya dapat dilihat pada tabel 5 .

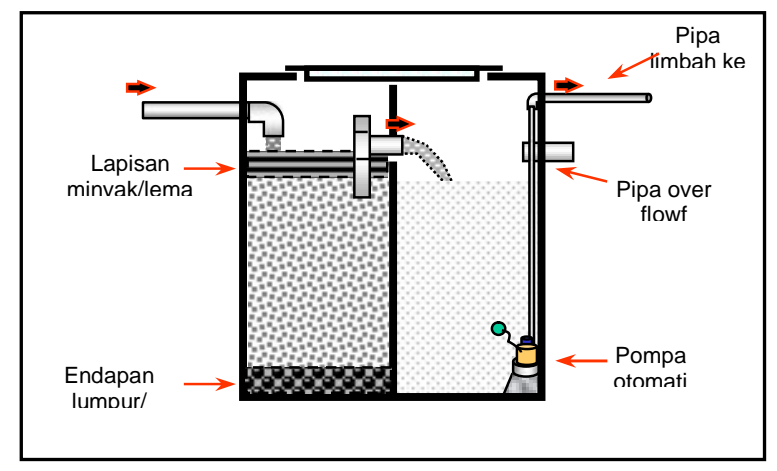

Gambar 4. Sketsa Bak Pengumpul Air Limbah

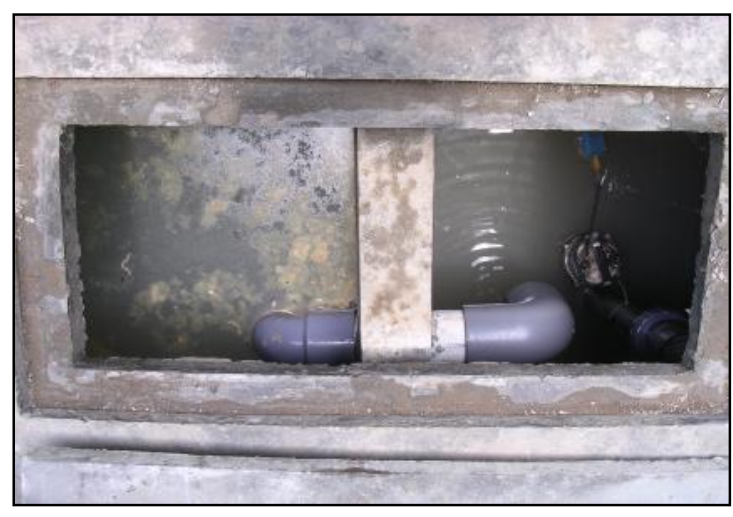

Gambar 5. Bak Pengumpul Air Limbah

\subsection{Sistem Pengolahan Air Limbah Domestik di IPAL}

Air limbah dari seluruh bak pengumpul dialirkan ke bak pemisah lemak atau minyak yang menyatu dengan bak ekualisasi seperti yang ada pada gambar 1 pada lampiran. Bak pemisah lemak tersebut berfungsi untuk memisahkan lemak atau minyak yang berasal dari kegiatan dapur, serta untuk mengendapkan kotoran pasir, tanah atau senyawa padatan yang tak dapat terurai secara biologis dan tidak sempat terpisahkan pada bak bak pengumpul.

Selanjutnya limpasan dari bak pemisah lemak dialirkan ke bak ekualisasi yang berfungsi sebagai bak penampung limbah dan bak kontrol aliran. Waktu tinggal hidrolis (WTH) di bak ekualisasi dirancang 8 jam. Air limbah di dalam bak ekualisasi selanjutnya dipompa ke unit IPAL. Di dalam unit IPAL, pertama air limbah dialirkan masuk ke bak pengendap awal dengan waktu pengendapan 2-3 jam, untuk mengendapkan partikel lumpur, pasir dan kotoran organik tersuspensi. Selain sebagai bak pengendapan, juga berfungsi sebagai bak pengurai senyawa organik yang berbentuk padatan, sludge digestion (pengurai lumpur) dan penampung lumpur.

Air limpasan dari bak pengendap awal selanjutnya dialirkan ke bak kontaktor anaerob (biofilter Anaerob) dengan arah aliran dari atas ke bawah. Di dalam bak kontaktor anaerob tersebut diisi dengan media khusus dari bahan plastik tipe sarang tawon. Jumlah bak kontaktor anaerob terdiri dari satu ruangan. Penguraian zat-zat organik yang ada dalam air limbah dilakukan oleh bakteri anaerobik atau fakultatif aerobik ${ }^{(1,3)}$. Setelah beberapa hari operasi, pada permukaan media filter akan tumbuh lapisan film mikro-organisme. Mikro-organisme inilah yang akan menguraikan zat organik yang belum sempat terurai pada bak pengendap. WTH di bak kontaktor anaerob dirancang 8 jam. 
Air limbah dari bak kontaktor (biofilter) anaerob dialirkan ke bak kontaktor aerob. $\mathrm{Di}$ dalam bak kontaktor aerob ini diisi dengan media khusus dari bahan plastik tipe sarang tawon, sambil diaerasi atau dihembus dengan udara sehingga mikro organisme yang ada akan menguraikan zat organik yang ada dalam air limbah serta tumbuh dan menempel pada permukaan media. Dengan demikian air limbah akan kontak dengan mikro-orgainisme yang tersuspensi dalam air maupun yang menempel pada permukaan media yang mana hal tersebut dapat meningkatkan efisiensi penguraian zat organik, serta mempercepat proses nitrifikasi, sehingga efisiensi penghilangan ammonia menjadi lebih besar. Proses ini sering di namakan Aerasi Kontak (Contact Aeration) (3). WTH di bak kontaktor aerob dirancang 12 jam.

Dari bak aerasi, air mengalir ke bak pengendap akhir. Di dalam bak ini lumpur aktif yang mengandung mikro-organisme diendapkan dan sebagian air dipompa kembali ke bagian bak pengendap awal dengan pompa sirkulasi lumpur. Debit pompa sirkulasi ini dapat diatur dengan buka tutup kran. Sama halnya dengan di bak pengendap awal, WTH di bak pengendap akhir dirancang 2-3 jam.

Sebagian air di bak pengendap akhir melimpas (outlet/over flow) melalui weir menuju ke bak pengolah lanjut. Di bak pengolah lanjut ini air limbah olahan IPAL di proses lagi dengan biofilter aerobik. Bak pengolah lanjut ini terdiri dari 5 ruang. Ruang pertama adalah ruang aerasi, ruang kedua ruang biofilter aerobik, ruang ketiga penampung air olahan, ruang ke empat ruang biokontrol dan ruang ke lima adalah ruang penampung air untuk diproses UF. Dari ruang aerasi, air limbah selanjutnya mengalir ke ruang biofilter aerobik dengan arah aliran dari bawah keatas. Dari biofilter aerobik air limbah melimpas melalui weir menuju ke ruang penampung air limbah. Dari ruang penampung air limbah ini dipompa menuju filter karbon, sebagian yang tidak sempat terpompa akan melimpas ke saluran pembuangan melalui flow meter. Dari filter karbon air limbah selanjutnya dialirkan menuju ke bak penampungan untuk diproses Ultrafiltrasi sambil diijeksikan khlor melalui pompa dozing.

Ultra filtrasi yang digunakan terdiri dari 8 membran dengan kapasitas sekitar $80 \mathrm{~m}^{3}$ per hari yang ditempatkan bersama filter karbon di dalam ruang operator. Alat ini beroperasi secara otomatis yang diatur dengan PLC. Air olahan ultra filtrasi ditampung pada bak penampung reuse yang berlokasi di samping ruang operator. Apabila air di bak penampung re-use ini penuh, maka akan terjadi overflow. Over flow ini dialirkan ke bak biokontrol dan selanjutnya apabila di bak biokontrol ini penuh maka akan melimpas ke saluran pembuangan melewati flow meter bersama dengan air olahan IPAL.

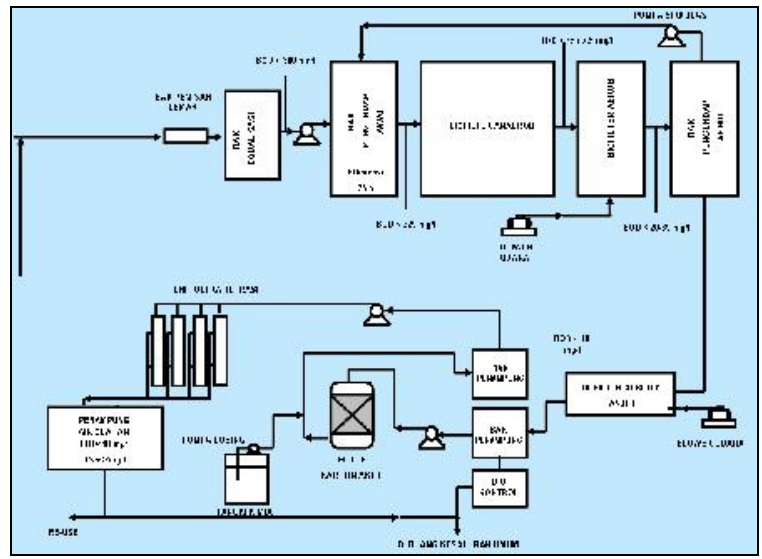

Gambar 6. Diagram Proses Pengolahan Air limbah Domestik PT. UCC dengan Proses

Biofilter Anaerob - Aerob yang dilengkapi proses re-use

\subsection{Prosedur Start-Up IPAL}

Start-up IPAL dilakukan pada saat IPAL baru selesai dibangun atau pada saat terjadi masalah besar sehingga perlu total pengurasan. Untuk melakukan start-up IPAL, langkah pertama yang harus dilakukan adalah pengecekan sistem IPAL secara keseluruhan. Pengecekan IPAL meliputi pengecekan kebocoran bak, pengecekan perpipaan dalam IPAL, pengecekan sistem kelistrikan, pengecekan pompa-pompa, pengecekan sistem suplai udara ke reaktor aerobik dan pengecekan bak-bak pengumpul. Setelah yakin kalau sistem IPAL sudah sempurna, selanjutnya dilakukan pengisian IPAL dengan urutan sebagai berikut:

1. Semua aliran air limbah dari sumber limbah ke bak pengumpul disambung, pompa di bak pengumpul dihidupkan, sehingga aliran air limbah akan menuju ke bak pemisah lemak yang menyatu dengan ekualisasi. Biarkan bak ekualisasi terisi penuh dengan air limbah sampai air limbah over flow melalui pipa menuju ke saluran air hujan. Sistem over flow ini dibuat untuk mengantisipasi kalau pompa di bak ekualisasi ada kerusakan sehingga tidak terjadi luapan air di ekualisasi. Pada posisi penuh dengan air limbah, cek semua dinding bak ekualisasi apakah ada kebocoran atau tidak.

2. Selanjutnya air limbah dari bak ekualisasi dipompa ke IPAL (bioreaktor/bak anaerobikaerobik dan pengendap akhir) sampai mencapai level penuh. Pengisian IPAL diusahakan merata jangan sampai sebagian penuh, bagian yang lain masih kosong. Ini dimaksudkan untuk meratakan beban air di 
IPAL guna menghindari risiko retaknya beton.

3. Setelah IPAL penuh selanjutnya blower pada bak aerobik dihidupkan dan cek apakah udara keluar melalui difuser secara merata atau tidak. Kalau tidak merata maka perlu perbaikan difuser udara.

4. Langkah selanjutnya adalah mengisi IPAL dengan bibit atau seed mikroba atau bakteri. Seed mikroba diambilkan dari instalasi pengolahan air limbah domestik yang sudah diketahui kinerjanya berjalan dengan baik. Jumlah seed mikroba sekitar $5-10 \mathrm{~m}^{3}$ Untuk kasus PT. UCC, seeding mikroba dilakukan secara alami tanpa tambahan mikroba dari luar. Ini dilakukan untuk menghindari bau yang dapat timbul karena ada sebagian mikroba yang mati pada saat seeding. Apabila proses pertumbuhan mikroba lambat (ditandai dengan kualitas hasil IPAL jelek) maka harus dilakukan seeding mikroba.

5. Selanjutnya hidupkan pompa sirkulasi, dengan demikian mikroba lama kelamaan akan tumbuh dan melekat pada permukaan media biofilter.

6. Pompa air limbah di bak equalisasi dihidupkan dan kecepatan alir di atur sebagai berikut :

- Minggu pertama : Aliran dibuat diatur sebesar $60 \mathrm{~m}^{3} /$ hari

- Minggu kedua : Aliran diatur sebesar 100 $\mathrm{m}^{3} /$ hari

- Minggu ke tiga : Aliran air limbah di set sampai kapasitas maksimum, yaitu 130 $\mathrm{m}^{3}$ per hari.

Debit air limbah dapat dipantau dari jalannya meteran air limbah yang ada di outlet IPAL maupun yang ada di Inlet filter karbon. Dan pengaturan debit dilakukan dengan memperbesar dan memperkecil bukaan valve yang ada pada sistem perpompaan di bak equalisasi.

Setelah selesai masa seeding, selanjutnya dilakukan pemantauan secara kontinyu (swapantau) dan evaluasi kinerja IPAL.

\section{HASIL ANALISIS KINERJA IPAL DOMESTIK PT. UNITED CAN}

Untuk melihat kinerja IPAL domestik IPAL PT. UCC maka secara berkala telah dilakukan pemantauan baik dengan cara pengamatan langsung dilapangan maupun melalui analisa laboratorium untuk melihat parameter-parameter polutan dalam air limbah dan air olahan. Parameter yang dianalisa adalah parameter yang tercakup dalam Surat Keputusan Gubernur DKI Jakarta No. 122 tahun 2005 tentang Baku Mutu Air Limbah Domestik, meliputi: derajat keasaman $(\mathrm{pH})$, chemical oxygen demand (COD), biochemical oxygen demand $\left(\mathrm{BOD}_{5}\right)$, total suspended solid (TSS), minyak/lemak, senyawa diterjen (MBAS), amonia, senyawa organik $\left(\mathrm{KMNO}_{4}\right)$. Berikut ini disajikan hasil-hasil pengamatan dan hasil analisa laboratorium dalam bentuk grafik serta bahasan terhadap hasil tersebut.

\subsection{Debit Air Limbah Yang Masuk IPAL}

Seperti terlihat pada Gambar 7, pada awal beroperasinya IPAL jumlah air limbah yang masuk IPAL cukup tinggi dan berfluktuasi antara 70 sampai $100 \mathrm{~m}^{3} /$ hari. Mulai hari ke 22 sampai hari ke 34 jumlah air limbah masuk IPAL sangat kecil antara 25 sampai $60 \mathrm{~m}^{3} /$ hari. Hal disebabkan karena ada perbaikan pada BP4 sehingga air limbah dari BP4 ini tidak dialirkan masuk IPAL. Mulai hari ke 35 air limbah dari BP4 sudah dimasukkan kembali kedalam IPAL sehingga jumlah inlet IPAL naik lagi. Seperti terlihat dalam gambar ini, diperkirakan jumlah air limbah dari BP4 ini sekitar separoh dari jumlah air limbah domestik yang dihasilkan PT. UCC. Setelah hari ke 35, total air limbah yang masuk IPAL relatif berkurang dibanding pada hari-hari awal IPAL beroperasi. Hal ini diduga karena adanya penghematan pemakaian air bersih setelah ada sosialisasi IPAL kepada karyawan PT. UCC, sehingga jumlah air limbah yang masuk IPAL juga berkurang. Diharapkan langkah-langkah penghematan pemakaian air bersih dapat berjalan terus, sehingga beban IPAL juga akan menjadi berkurang.

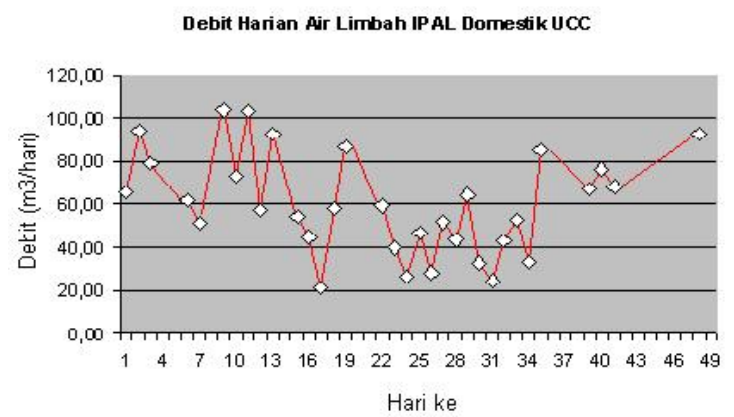

Gambar 7. Debit Air Limbah

\subsection{Chemical Oxygen Demand (COD)}

Hasil analisa konsentrasi COD baik inlet maupun outlet IPAL disajikan pada Gambar 8 . Dalam gambar ini juga diplot effisiensi pengurangan COD, yaitu COD inlet dikurangi COD outlet IPAL kemudian dibagi COD inlet dan dikali $100 \%$. COD dianalisa seminggu sekali. Secara umum konsentrasi COD dalam limbah domestik sekitar 200-300 mg/l (3). Konsentrasi 
COD yang masuk IPAL PT. UCC berkisar antara 150 sampai $325 \mathrm{mg} / \mathrm{l}$, berada dalam batasan umum limbah domestik. Sedangkan COD out IPAL berkisar dan 40 sampai $60 \mathrm{mg} / \mathrm{l}$, jauh dibawah baku mutu yang ditetapkan pemerintah yaitu $80 \mathrm{mg} / \mathrm{l}$. Seiring dengan berjalannya waktu, kinerja IPAL juga meningkat yang ditandai dengan naiknya effisiensi mengurangan COD, yaitu diatas $80 \%$ setelah minggu ke 6 . Hal ini terjadi karena mikroba pengurai polutan limbah terus tumbuh dan berkembang biak disamping sudah beradaptasi dengan limbah domestik PT. UCC.

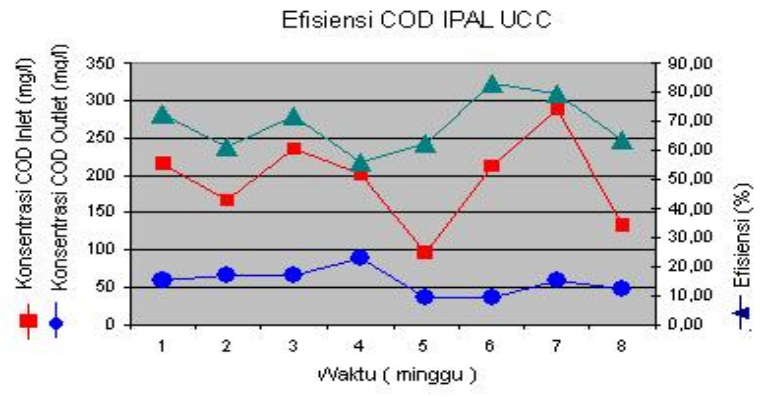

Gambar 8. Konsentrasi dan Efisiensi Penurunan COD

\subsection{Biologycal Oxygen Demand (BOD)}

Secara umum untuk limbah organik seperti limbah domestik, performan konsentrasi BOD hampir sama dengan COD. Seperti terlihat pada Gambar 9, konsenrasi BOD dalam air olahan IPAL berkisar antara 15 sampai $20 \mathrm{mg} / \mathrm{l}$, jauh di bawah baku mutu yang ditetapkan pemerintah yakni $50 \mathrm{mg} / \mathrm{l}$. Effisiensi pengurangan BOD juga naik sering dengan lamanya IPAL beroperasi yang menandakan mikroba makin banyak dan makin aktif. Effisiensi pengurangan BOD di atas $80 \%$ setelah minggu ke 6 .

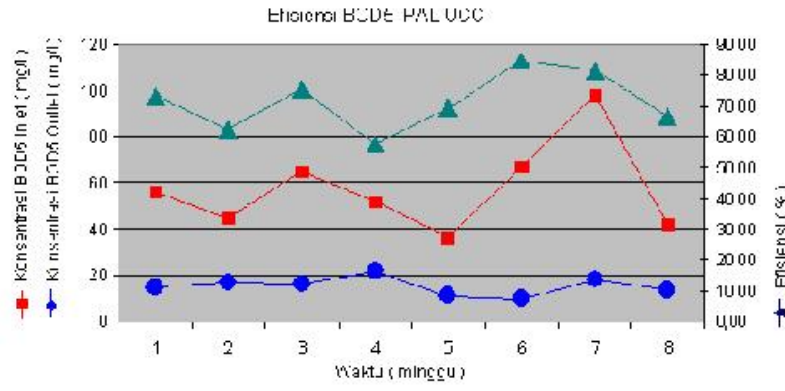

Gambar 9. Konsentrasi Dan Efisiensi Penurunan BOD

\subsection{Amonia Nitrogen $\left(\mathrm{NH}_{3}-\mathrm{N}\right)$}

Gambar 10 adalah konsentrasi amonia Nitrogen $\left(\mathrm{NH}_{3}-\mathrm{N}\right)$ sebelum masuk dan setelah keluar IPAL serta effisiensi pengurangannya. Pada awal-awal IPAL beroperasi, konsentrasi amonia sangat berfluktuasi, bahkan pada minggu ke 3 konsentrasi amonia dalam air olahan IPAL lebih tinggi inlet IPAL. Hal ini diduga karena ada pembuangan bahan-bahan kimia yang mengandung amonia kedalam saluran air limbah domestik. Setelah minggu ke 5 IPAL beroperasi, konsentrasi amonia dalam air limbah dan dalam air olahan IPAL masing-masing sekisar $0,1 \mathrm{mg} / \mathrm{l}$ dan $0,01 \mathrm{mg} / \mathrm{l}$. Baku mutu untuk amonia nitrogen adalah $10 \mathrm{mg} / \mathrm{l}$. Effisiensi pengurangan amonia sangat tinggi diatas $90 \%$.

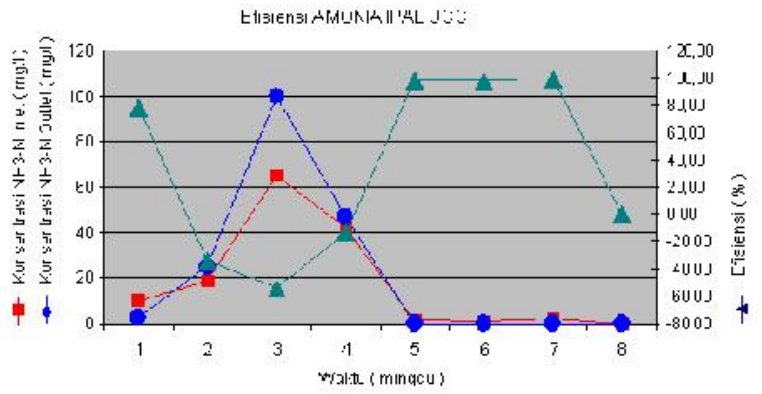

Gambar 10. Konsentrasi dan Efisiensi Penurunan Amonia

\subsection{Total Suspended Solid (TSS)}

TSS adalah jumlah partikel padat polutan yang tersuspensi dalam air limbah. Seperti terlihat pada Gambar 11, mulai dari saat IPAL start-up sampai hari terakhir sampling, konsentrasi TSS dalam air olahan IPAL berada dibawah $10 \mathrm{mg} / \mathrm{l}$, jauh dari konsentrasi yang dipersyaratkan pemerintah yakni $50 \mathrm{mg} / \mathrm{l}$. Effisiensi pengurangan TSS juga sangat tinggi, $80 \%$ sampai $90 \%$. Rendahnya TSS ini kemungkinan disebabkan oleh pemisahan padatan di setiap bak pengumpul dan oleh karena proses pengendapan dan biofiltrasi di IPAL.

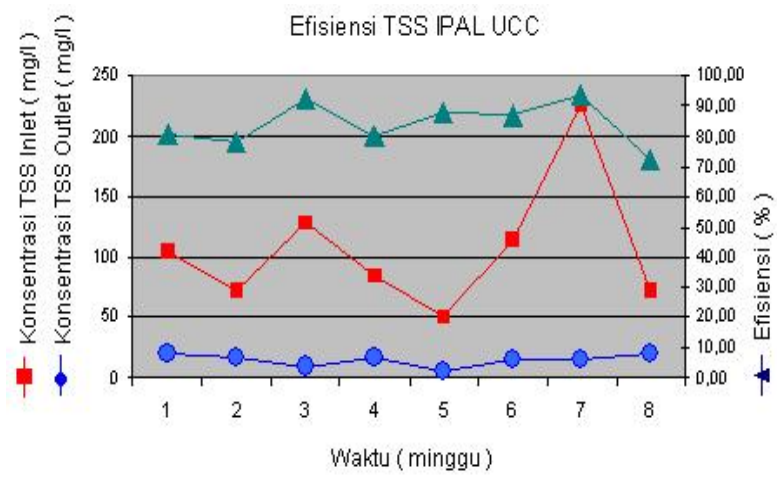

Gambar 11. Konsentrasi dan Efisiensi Penurunan TSS 


\subsection{Senyawa Organik Permanganat $\left(\mathrm{KMnO}_{4}\right)$}

Seperti terlihat pada gambar 12 , sampai minggu ke 6 senyawa organik $\mathrm{KMnO}_{4}$ yang masuk IPAL relatif stabil sekitar $100 \mathrm{mg} / \mathrm{l}$. Pada minggu ke 7 naik hampir $300 \mathrm{mg} / \mathrm{l}$. Namun meskipun demikian konsentrasi senyawa organik $\mathrm{KMnO}_{4}$ dalam air olahan IPAL relatif stabil antara 20 sampai $40 \mathrm{mg} / \mathrm{l}$, jauh dibawah baku mutu yakni $85 \mathrm{mg} / \mathrm{l}$. Effisiensi pengurangan senyawa organik $\mathrm{KMnO}_{4}$ setelah minggu ke 6 sangat tinggi, sekitar $90 \%$

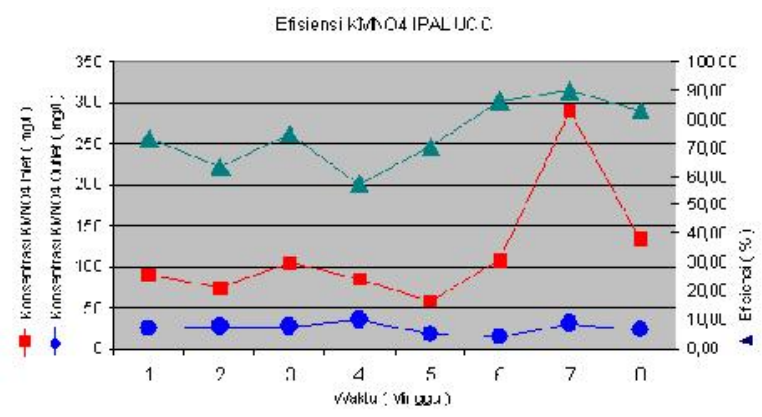

Gambar 12. Konsentrasi dan Efisiensi Penurunan Organik $\mathrm{KMnO}_{4}$

\subsection{Minyak Dan Lemak}

Gambar 13 adalah konsentrasi minyak dan lemak dalam air limbah yang masuk dan keluar IPAL serta effisiensi pengurangan minyak dan lemak dalam IPAL. Seperti terlihat disini, meskipun konsentrasi minyak dan lemak yang masuk IPAL cukup tinggi dan sangat berfluktuasi namun dalam air olahan IPAL konsentrasinya dapat diturunkan sampai dibawah $0,5 \mathrm{mg} / \mathrm{l}$. nilai ini jauh dibawah baku mutu yang ditetapkan pemerintah yaitu $10 \mathrm{mg} / \mathrm{l}$. Effisiensi pengurangan minyak dan lemak dalam IPAL diatas 90\% setelah minggu ke 5. Hal ini menandakan bahwa sistem pemisahan minyak lemak baik di BP maupun bak pemisah lemak minyak IPAL sudah berfungsi dengan baik.

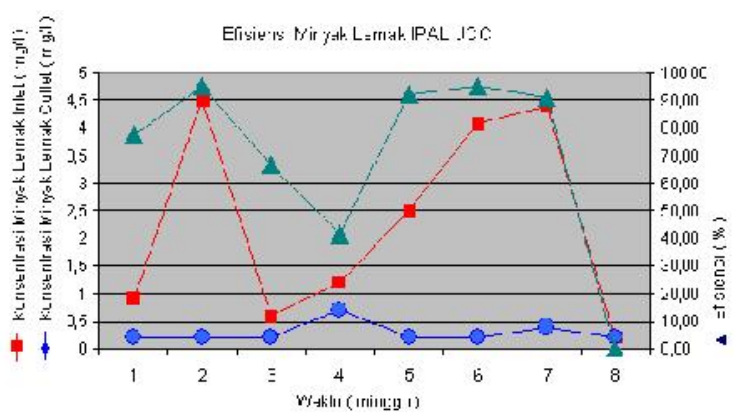

Gambar 13. Konsentrasi dan Efisiensi Penurunan Minyak dan Lemak

\subsection{Senyawa Deterjen (MBAS)}

Senyawa deterjen (MBAS) yang masuk IPAL juga berfluktuasi (Gambar 14), namun dalam air hasil olahan IPAL konsentrasinya dapat diturunkan sampai dibawah $0,8 \mathrm{mg} / \mathrm{l}$ dengan effisiensi pengurangan sekitar $80 \%$. Baku mutu deterjen (MBAS) adalah $2 \mathrm{mg} / \mathrm{l}$.

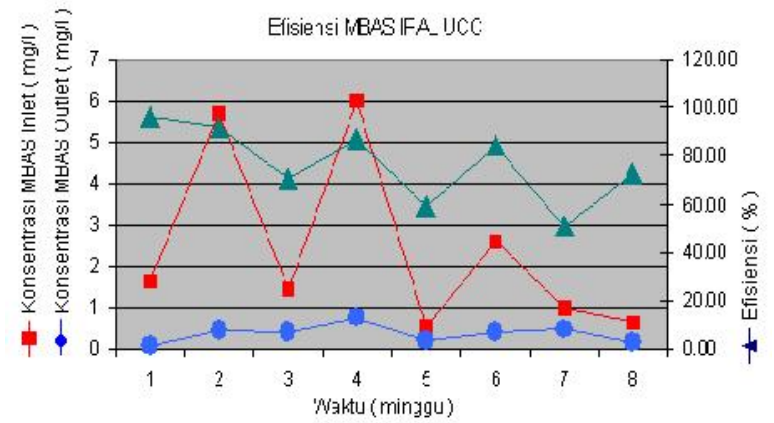

Gambar 14. Konsentrasi dan Efisiensi Penurunan Deterjen (MBAS)

\subsection{Hasil Olahan Unit Daur Ulang}

Seperti dijelaskan diatas, unit daur ulang air limbah domestik di UCC menggunakan filter karbon dan ultra filtrasi. Pada pengamatan di hari yang sama yang di lakukan untuk air inlet IPAL, outlet IPAL dan air olahan unit daur ulang menunjukkan bahwa kualitas air untuk semua parameter yang tertuang dalam Pergub 122 tahun 2005 mengalami perbaikan kualitas air yang cukup signifikan setelah di proses ultra filtrasi. Data kualitas air ditunjukkan pada tabel 6. Dari data tersebut menunjukkan bahwa membran ultra filtrasi sangat efektif untuk menghilangkan kekeruhan atau TSS, dapat mengurangi kandungan organik, MBAS, dan deterjen. Namun tidak dapat menghilangkan senyawa terlarut tersebut ${ }^{(7)}$.

Tabel 6. Hasil Analisa Kualitas Air IPAL Domestik dan Unit Daur Ulang

\begin{tabular}{|c|c|c|c|c|}
\hline No & Parameter & $\begin{array}{l}\text { INFLUEN } \\
\text { IPAL }\end{array}$ & $\begin{array}{l}\text { EFLUENT } \\
\text { IPAL }\end{array}$ & $\begin{array}{l}\text { EFLUENT } \\
\text { RE-USE } \\
\text { (ULTRA } \\
\text { FILTRASI) }\end{array}$ \\
\hline 1 & $\mathrm{pH}\left(26^{\circ} \mathrm{C}\right)$ & 76 & 7,9 & 8.1 \\
\hline 2 & Nilai Permanganat $(\mathrm{mg} / \mathrm{f})$ & $107: 9$ & 14,6 & 7.2 \\
\hline 3 & TSS (mg/l) & 115 & 15 & 0 \\
\hline 4 & Amonia Bebas $(\mathrm{mg} / \mathrm{l})$ & 0.56 & 0,01 & 0.02 \\
\hline 5 & Mlinyak Lemak (mg/l) & $4: 1$ & 0,2 & 0.2 \\
\hline 6 & Deterjen $(\mathrm{mg} / \mathrm{l})$ & 261 & 0,4 & 0.16 \\
\hline 7 & $\mathrm{BOD}(\mathrm{mg} /)$ & 67 & 10 & 5 \\
\hline 8 & $\operatorname{cod}(\mathrm{mg} / \mathrm{l})$ & 213 & 36 & 15 \\
\hline
\end{tabular}




\section{KESIMPULAN}

Instalasi Pengolahan Air Limbah Domestik Pabrik Kaleng PT. United Can menggunakan proses biologis biofilter anaerobaerob. Kinerja dari IPAL ini selama 3 bulan pertama setelah pengoperasian awal IPAL, menunjukkan hasil yang bagus.

Dari pengamatan kualitas air hasil olahan IPAL yang meliputi parameter $\mathrm{pH}, \mathrm{COD}, \mathrm{BOD}$, TSS, Minyak dan Lemak, Amonia dan Deterjen menunjukkan angka yang aman untuk dibuang ke lingkungan. Kesemua parameter tersebut sudah memenuhi syarat Peraturan Gubernur DKI 122 tahun 2005 tentang limbah domestik.

Air hasil proses daur ulang dengan filter karbon dan ultra filtrasi menunjukkan kualitas yang lebih baik dari olahan IPAL. Air ini berpotensi untuk dapat dipergunakan sebagai air cucian lantai, mesin, maupun untuk siram taman.

\section{DAFTAR PUSTAKA}

1. Degreemont, "Water Treatment Handbook, sixth edition, 1991.

2. Langlais, B., D.A. Rechkov, D.R. Brink, "Ozon in Water Treatment, Application in Engineering", Lewis Publisher and AWWA Research Foundation, USA, 1991.

3. Mc.Calf and Eddy, "Wastewater Engineering", Mc Graw Hill, 1978.

4. Octave Levenspiel, "Chemical Reaction Engineering, John Willey and Sons, Inc. $2^{\text {rd }}$. ed, 1972.

5. Pemda DKI Jakarta, Peraturan Gubernur DKI Jakarta No. 122/2005 tentang Baku Mutu Limbah Cair Domestik, 2005.

6. Nugroho, R. Pemilihan Teknologi yang Tepat untuk Pengolahan Air Limbah Domestik di Perkotaan. PTL-BPPT. Jakarta, 2006.

7. Nugroho, R. Membran dan Desalinasi Perkotaan. Makalah Pelatihan Teknologi Pengolahan Air Bersih, PTL-BPPT. Jakarta, 2006

8. PU-JICA. Studi Limbah Domestik DKI Jakarta, 1991. 


\section{LAMPIRAN :}

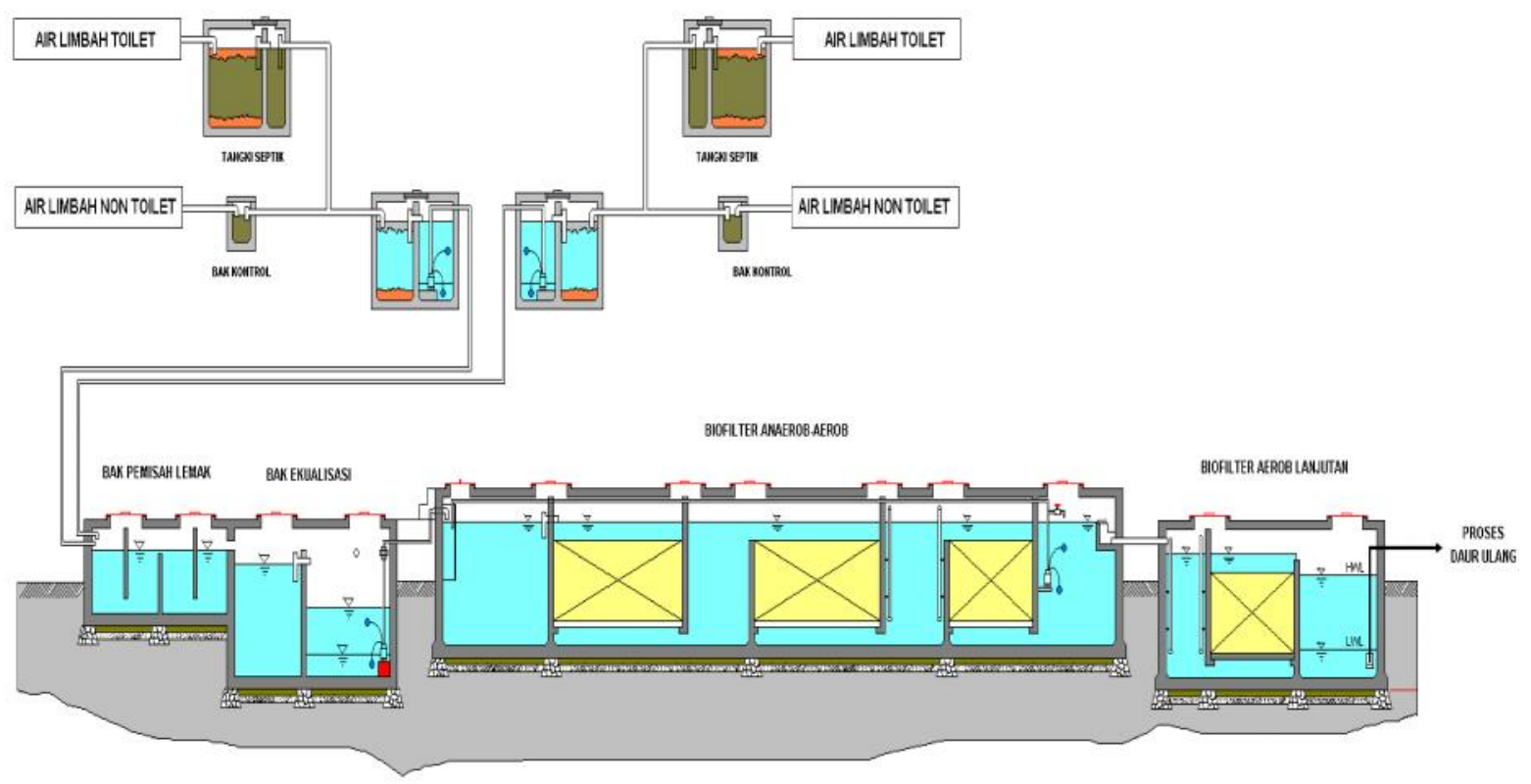

Gambar 1. Flow Proses IPAL Domestik PT. UCC dengan Biofilter Anaerob-aerob.

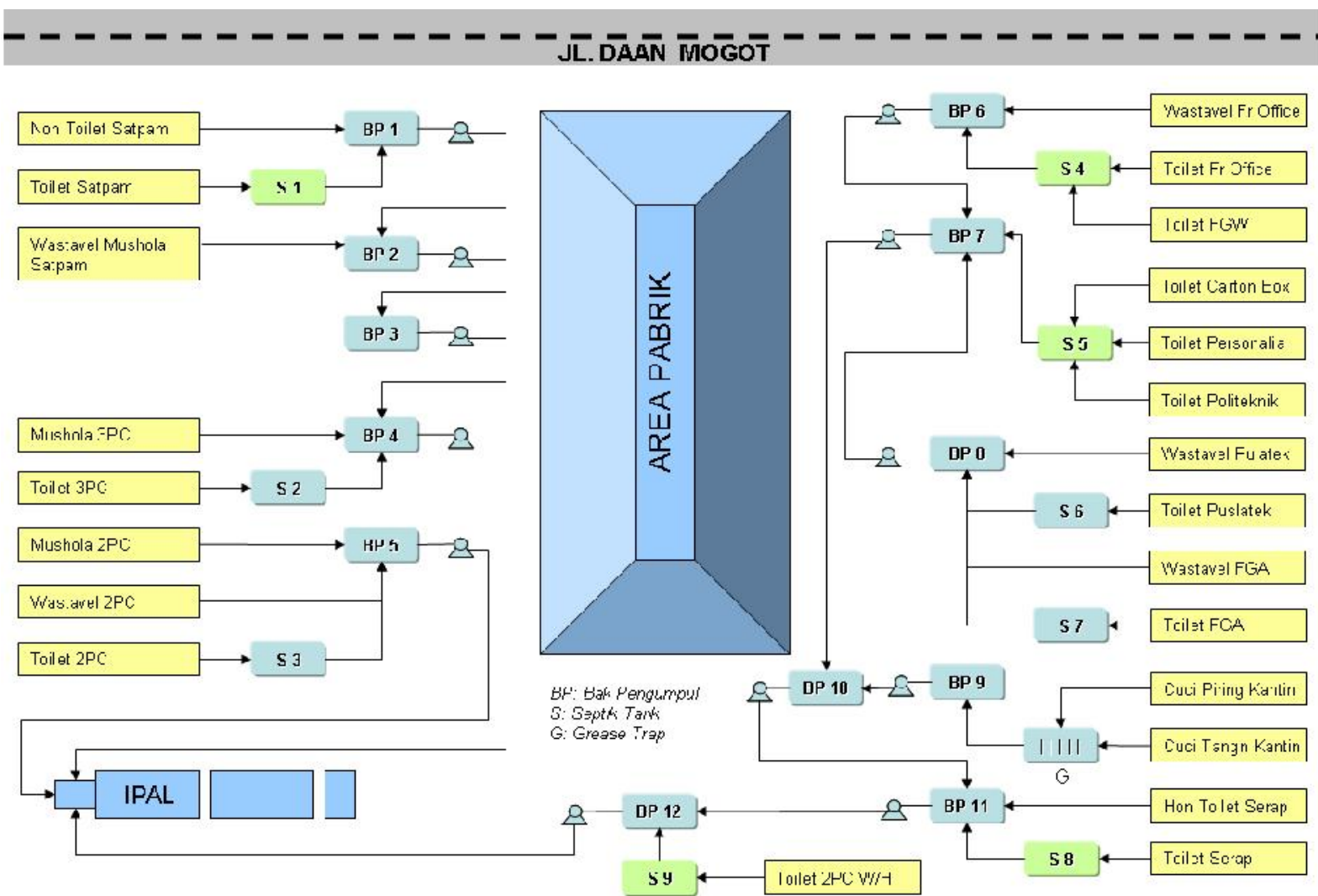

Gambar 3. Sistem Aliran Air Limbah dari Sumber menuju IPAL. 
Tabel 5. Lokasi bak pengumpul dan tipe pompa pada setiap bak.

\begin{tabular}{|c|c|c|c|c|c|}
\hline No & $\begin{array}{l}\text { Kode Bak } \\
\text { Pengumpul }\end{array}$ & Lokasi & Arah Aliran & $\begin{array}{l}\text { Jarak } \\
\text { Pompaan }\end{array}$ & Tipe pompa \\
\hline 1 & $B^{-1}$ & Fos Satpam & $\mathrm{Ke} 3 \vdash^{2}$ & ES m & $=B A$ RA SOLV VSA 5.4 \\
\hline 2 & $B^{2} 2$ & Must ola parkir rrotor & $\mathrm{Ke} 3 \mathrm{P} 3$ & $70 \mathrm{~m}$ & EBARA 50 C VSA 5.4 \\
\hline 3 & $B^{\circ} 3$ & $\begin{array}{l}\text { Area Kosong Belakang } \\
\text { Pearkil riulur }\end{array}$ & $\mathrm{Ke} 3 \mathrm{P} 4$ & $138 \mathrm{~m}$ & EBARA 50 CVSA 5.75 \\
\hline 4 & $B^{2} 4$ & Samping 3PC & Ké IPAL & $172 \mathrm{~m}$ & $\begin{array}{l}\text {-Ceriltifug:al purnp Ebara, Tipe } \\
2 \mathrm{H} A 52.2 \text {. Head } 30 \mathrm{~m} \text {, rotor tecco } 2.2 \\
\text { iW }\end{array}$ \\
\hline 5 & $B^{=} 5$ & Eamping $2 \mathrm{~F}-$ & Ke IFAL & $57 \mathrm{~m}$ & EBARA $50 \mathrm{U}$ VSA 5.4 \\
\hline 6 & $B^{\supset} 6$ & Front Office & $\mathrm{Ke} 3 \mathrm{P} 7$ & $150 \mathrm{~m}$ & EBARA 50CVSA 5.75 \\
\hline 7 & $B^{2} 7$ & Samping Perso-po iklinik & $\mathrm{Ke} 3 \mathrm{P} 10$ & $230 \mathrm{~m}$ & $\begin{array}{l}\text {-Centrifugal pump Ebara. Tipe } \\
2 \mathrm{H}, 5.52 .2, \text { Head } 30 \mathrm{~m} \text {, rotor tecco } 2,2 \\
\langle\mathrm{~W}\end{array}$ \\
\hline 8 & $B=8$ & Liepan Pusla:ek & Ke $\lrcorner \vdash \prime$ & $50 \mathrm{~m}$ & $=B A . R A S O L V S A B S .4$ \\
\hline 9 & $B^{\supset} 9$ & Kantin & $\mathrm{Ke} 3 \mathrm{P} 10$ & $110 \mathrm{~m}$ & EBARA 50 CVSA 5.75 \\
\hline 10 & $B^{\supset} 10$ & Eelakang SCA & $\mathrm{Ke} 3 \mathrm{P} 11$ & $70 \mathrm{~m}$ & EBARA 50 CVSA 5.75 \\
\hline 11 & $B^{\prime} 1^{\prime}$ & Eelakang Toilet Scrap & Ke $3 \Gamma 12$ & $130 \mathrm{~m}$ & 三ВА.RА 65С VऽА 51.5 \\
\hline 12 & $B^{2} 12$ & Eelakianly Tuilel zPC WHH & K'e IPAL & $217 \mathrm{III}$ & $\begin{array}{l}\text {-Cerilrifug=1 purnp Evara, Tipe } \\
2 \mathrm{H} A 52.2 \text {. Head } 30 \mathrm{~m} \text {. rotor tecco } 2.2 \\
\langle\mathrm{~W}\end{array}$ \\
\hline
\end{tabular}

